\title{
Early grade teachers' awareness and skills on multiliteracies pedagogies
}

\author{
Nani Babu Ghimire \\ Lecturer, Siddhajyoti Education Campus, Sindhuli, Nepal \\ Yam Prasad Pandeya \\ Lecturer, Siddhajyoti Education Campus, Sindhuli, Nepal
}

\begin{abstract}
Multiliteracies is a pedagogical approach developed in 1994 by the New London Group (NLG) that aims to make classroom teaching more inclusive by addressing cultural and linguistic diversity, and rapid development in communication channel and technology. The purpose of this study was to explore the early grade teachers' perception on multiliteracies pedagogy and their awareness, skills and proficiency on it. We used critical ethnography research design to obtain rich and in-depth data from five years' experienced three early grade teachers through interviews and participant classroom observation in a community school of Nepal. Interviews and class observation of teachers were audio-recorded, and recorded data were transcribed assigning codes, and main two themes were developed in terms of the codes. Regarding understanding and awareness on multiliteracies pedagogy, the findings reveal that the teachers do not have more clear theoretical concept on it. They perceive multiliteracies as being literate not only through reading and writing but also using pictures, signs, symbols and mimics. They are aware in the use of multiliteracies pedagogy to make teaching learning effective but they do not have sufficient skills and proficiency on it. They can apply multiliteracies pedagogy in early grades effectively if their knowlwdge and skills is developed through training and capacity development programme on it.
\end{abstract}

Keywords: Multiliteracies, multiliteracies pedagogy, early grade, awareness, skills

\section{Introduction}

Multiliteracies is a pedagogical approach developed in 1994 by the New London Group (NLG) that aims to make classroom teaching more inclusive of cultural, linguistic, communicative, and technological diversity. They advocate this so that students will be better prepared for a successful life in a globalized world. It is also considered as essential aspect in day-to-day life. New London Group (1996) asserts that multiliteracies pedagogy accepts and encourages a wide range of linguistic, cultural, communicative, and technological perspectives and tools being used to help students better prepare for a rapidly changing, globalized world. The 
schools need to adapt the growing availability of new technologies for teaching and learning, communication channels, and increased access to cultural and linguistic diversity in order to make students learning effective based on the development of social need. Concerning on explosion of globalization and communication technology, Elsner (2011) mentions that:

There has been a steady rise of cultural and linguistic diversity, due to migration, multiculturalism and global economic integration; there has been the rapid development of technological devices and the world-wide expansion of new communications media. These changes directly affect the lives of our pupils at home and at school and thus have an important impact on curricular development, teaching objectives, contents and methodologies - starting as early as in primary school. (p.27)

The literacy landscape in the 21 st century has shifted from a print saturated system to a multimodal semiotic system. Utilising multiliteracies pedagogy is considered the most effective way to integrate modern technology in early grades. Mills (2009) argues for the need to review school based literacy practices, believing the definition of literacy should be broadened to encompass more than instructing students how to master sound-letter correspondence 'alphabetic' literacy.

Although there is growing use of multiliteracies pedagogy through the use of multimode and digital devices/strategies in the world, very little practice has been done in Nepal. The school education of Nepal is based on traditional way except in some reputed schools. Such type of practice cannot address the need of the society and demands of the students in this changing globalized world. Although Nepal is a developing country, there is an impact of globalization and use of information communication technology in its educational process. In this study, we have tried to explore the exciting situation of multiliteracies pedagogy since no detail studies have been done in this area. The main purpose of this study was to explore the early grade teachers' perception, awareness, skills and proficiency on multiliteracy pedagogy in Nepal. The research questions of this study were as follows:

1. How do the early grade teachers perceive multiliteracy pedagogy in classroom practice in Nepal?

2. What awarenesses and skills do the teachers have regarding multiliteracy pedagogy in early grades in Nepal? 


\section{Literature Review}

Classroom pedagogy is vital for the learning achievement of the students. Traditional pedagogy is not appropriate to address the need of today's children because the society has become diverse and developed because of the invention of different tools of technology and modes of learning. Describing this context, Elsner (2011) argues that linguistic diversity goes hand in hand with the rapid development of new information technology and the impact of globalization. People all over the world communicate with each other, exchange information, and read the same texts being at completely different places, speaking different languages. Ganapathy (2014) adds as it is vital that these changes are addressed in educational settings to meet the current demands and challenges of various societies which are vital to ensure that education is relevant to global standards.

Multiliteracies pedagogy builds on more traditional approaches of written linguistic meaning-making, and extends learning to incorporate what is new in the current environment (Kalantzis \& Cope, 2012). And thus, the multiliteracies pedagogy has received significant attention in international literacy research (Mills, 2009).The term multiliteracies was developed by the New London Group (NLG), a group of ten researchers, educators, and visionaries, in 1994 in New London, New Hampshire, USA from their manifesto entitled A Pedagogy of Multiliteracies: Designing Social Futures. (The New London Group, 1996). Based on their assessment of how new technologies were influencing society, the NLG devised the multiliteracies approach to address these changes; in particular, how technology changes and globalization were affecting education (Cope \& Kalantzis, 2000). The integration of teaching multiliteracies has a potential to adopt new ideas and overcome the limitations of traditional learning approaches in the 21 st century literacies.

The 'multiliteracies' argument has three components, framed as the 'why' of Multiliteracies, the 'what' of Multiliteracies, and the 'how' of Multiliteracies. Regarding the aspect of the 'why' of multiliteracies, it can be said that society is changing and the students need to receive the skills necessary for functioning in future studies and working life; it can be argued that teaching multiliteracies in schools is essential. Jarho (2017) claimed that taking multiliteracies into consideration in education can aid to fulfill these requirements and including multiliteracies into education can be viewed as aiding students to manage with their future lives as active members of society. Considering the aspect of the 'what' of multiliteracies, Cope and Kalantzis (2015) pointed out that the 'what' can be divided into two parts: the first is related to the multiple ways of communicating which refers 
to the ability to just reading text is not enough but one should be able to read and decipher and respond to it in the right way depending on the context; and the second aspect refers to multimodality - use of different modes such as written, oral, visual, audio, tactile, gestural and spatial for making meaning. Taking into account the aspect of the 'how' of multiliteracies addresses the issue of including multiliteracies into education and pedagogy. Neville (2015) suggested that students must now be taught how to read, view, write and create multimodal texts. The students can learn easily and effectively by using their own language and using various modes of communication in the classroom through different multi-model activities.

In the original formulation of the New London Group, the following major dimensions of literacy pedagogy were identified: situated practice, overt instruction, critical framing, and transformed practice (Cope \& Kalantzis, 2015). According to Benjamin (2014):

Situated practice draws on experience of meaning-making in specific contexts. Overt instruction develops an explicit meta-language to support active interventions that scaffold student learning. Critical framing makes sense of situated practice and overt instruction by interpreting the social contexts and purposes related to meaning making. The goal is to enact transformed practice where students, as meaning makers, become designers themselves and not just consumers. (p.116)

Different researchers, educators and scholars have done many studies on multiliteracies pedagogy in the the world. Giampapa (2010) in an ethnographic case study claimed that if education for twenty-first century is to prepare students to deal with the new demands on literacies and the rapidly changing technological terrain, educators should invest in students' multiliteracies and multilingual identities as resources inside classrooms and schools. Likewise, Simon (2011) in his study 'on the human challenges of multiliteracies pedagogy' asserted that educators and researchers interested in implications of multiliteracies for early childhood classrooms need to concern themselves with technological problems issues of equity are materially related to providing all children with access to new technologies. Souzandehfar, Saadat, and Sahragard (2014) in Iranian EFL learners found that the use of multimodal resources had the potential to foster language and literacy learning in a way that was transformative and was affected by the students' identities. Khadka (2014) carried out a research entitled 'new media, multiliteracies, and the globalized classroom' which showed that both undergraduate and graduate curricula need multiliterate orientations whereas faculty need decent compensation, and continual support and professional development opportunities in order for them 
to be willing and able to implement multiliterate approaches to teaching composition. Mills (2006) completed a research on 'multiliteracies: critical ethnography; pedagogy, power, discourse and access to multiliteracies' and concluded that cultural and linguistic diversity must be seen as a powerful classroom resource for access to multiliteracies, not only for marginalised group, but also for the benefit of all. Classroom must be places for the negotiation of regional, ethnic, or classbased dialects, hybrid cross-cultural discources and variations in register that occur according to social context.

A brief review of the literature shows that there is the primary and urgent need to bridge the large gap between the theories of multiliteracies and their practices in the context of the classroom. In the context of Nepal, some scholars have done research in multilingualism, diverse classroom, translanguaging, translingual practice in classroom pedagogy, but very limited studies have done regarding multiliteracies pedagogy. Thus, we have tried to do this study to explore the ideas of the perception, awareness and skills of teachers on multiliteracies pedagogy in early grades in Nepalese community school.

\section{Methods and Procedures}

We adopted critical ethnography research design to explore the awareness and skills of early grade teachers regarding multiliteracies pedagogy in this study. May (1997) states that critical ethnography attempts to move beyond the accounts of participants in particular settings to examine the ideological premises and hegemonic practices which shape and constrain these accounts. For this study, critical ethnography is a relevant approach for three reasons. First, we have selected a school as research site which is situated in a multilingual and multiethnic society and the team of school administration is curious to use multilingual and multimodal pedagogy in the classroom teaching. Second, the research was exploratory and needed a flexible methodology which was responsive to unpredictability. Third, it facilitates the use of inductive strategies to learn about cultural conditions, local knowledge and teaching approaches (Flick, 2002).

The educational context of this critical ethnographic study is "Shree Himalaya Secondary School (HSS)" (pseudonym) in a mid-eastern hilly district of Nepal. The demographic landscape for this school involves different communities such as Brahmins, Kshetris, Janajatis (e.g. Danuwar, Majhi, Tamang, Magar), and Dalits (e.g. Kami, Damai, Sarki). The school consisted of about 30 teachers who were predominantly from the Brahmins and the Kshetris, and of whom eight were racial and/or linguistic minority teachers. The linguistic landscape of the school was 
diverse, with the four common home languages being Nepali, Danuar, Majhi and Tamang. Students brought to school diverse culture, religions and varying degrees of their first language literacies and English language skills. The experienced teachers were selected purposively as participant of this study. As mentioned by Creswell (2012, p. 206), "in purposeful sampling, researchers intentionally select individuals and sites to learn or understand the central phenomenon", among 30, three teachers — one female, one janajati, and one Brahmin — who had been teaching at least five years in early grades at HSS were selected as participants for this study. To maintain privacy, confidentiality and anonymity, pseudonyms as Devraj, Harikala and Makarlal were used for all participants involved in this study.

We used in-depth interviewing and participant classroom observation to capture the participants' perception, awareness and skills on multiliteracies pedagogy. Talking about the use of interview, Blakeslee and Fleischer (2007) maintain, "Interviews are opportunities to explore with a participant in an indepth manner that provide insight into the person's thoughts, perceptions, feelings, motivations, responses, and actions in relation to the issues or situations being explored in the research" (p.129). Kothari (2004) has claimed that in participant classroom observation, the information is sought by way of investigator's own direct observation without asking from the respondent. Two "in-depth interviews" (January $\&$ March, 2020) were conducted with each participant (three early grade teachers) based on the 10 open-ended guideline questions. Observations in three classroom occurred three times over a six-month period for a minimum of three hours per visit. All interviews and classroom observation were audio recorded by us after taking the participants' permission. The audio recorded data were transcribed manually and developed the codes based on the transcription. Generated codes were clustered into categories according to similarity and regularity. The two main themes were developed and they were analysed and interpreted with thick description.

\section{Results and Discussion}

This section discusses the results of the study in terms of two themes as Understanding and awareness on multiliteracies pedagogy: Theoretically inadequate, and Skill and proficiency on multiliteracies pedagogy: Deficiency for application.

\section{Understanding and awareness on multiliteracies pedagogy: Theoretically inadequate}

The diverse classroom and explosion of modern technology drew the attention of the scholars to develop new pedagogy to teach the students of the 
modern world. In this context, the concept of mupltiliteracies pedagogy was emerged and extended globally. Regarding the understanding of multiliteracies pedagogy, Devraj viewed:

I understand literacy means being able in 'reading' letters and 'writing' them in paper with pen. Multiliteracies means being literate not only through reading and writing letters but also using pictures, signs and symbols. (Interview, 22 January, 2020)

This remark performs that Devraj does not have complete ideas about multiliteracies pedagogy but he has fundamental understanding of it. He perceived that being capable to read and write letters is adequate to teach but now it is not sufficient. Relating to this idea New London Group (1996) claimed that we need multiliteracies pedagogy to apply different communication channels/modes and media for making meaning to the children in the classroom. Boche (2014) stated that the teachers must respond to the different mediums and modes of teaching with new knowledge and multiple discourses in which students operate. In this context, we observed a class of English taught by Harikala at Grade three in which she taught a chant. The use of multilitearcies pedagogy in English class in the school is seen as observed in the following vignette:

\section{Vignette 1: Teaching chant}

She sang the chant in melodious tune and asked the students to follow her by clapping the hands. During teaching, she tried to use English language as a medium of instruction, but actually, the students were not getting point in English language. She used Nepali language to instruct the student during her teaching too. (Field note, 22 January 2020)

This class observation specifies us that the teacher has used multimodality factors in the classroom teaching. Vignette 1 shows that Harikala has used 'oral' as live speech and 'gestural' as movements of hands and arms, expression of face, eye movement of her as well as of students during teaching chants. In the interview, she said, "I do not know about multiliteracies pedagogy" (Interview, 22 January 2020), but she has applied the practice of multiliteracies in the classroom. It attests that Harikala has no idea of literal meaning of multiliteracy pedagogy but she usually teaches by using multimodality factors in the classroom. Talking about multimodality, Hughes and Morrison (2014, p. 612) said "meaning-making through many representational modes (spoken, written, visual, aural and interactive aspects)". In this sense, Harikala used spoken, visual and interactive aspects in the class during teaching chant in English class. She also used multiple languages such as English and Nepali to help the students for meaning making process. Likewise, Makarlal uttered: 
In fact, I cannot define multiliteracies pedagogy, but it may be the use of different multimodal materials and technology in teaching beyond only spoken by teachers. If we use multimodal materials and technology to teach in the classroom, it will be effective. (Interview, 10 March 2020)

The ideas mentioned by Makarlal illustrates that he does not have linguistic idea about multiliteracies pedagogy because he has not obtained higher education. However, he says that he is unfamiliar with multiliteracies pedagogy; he is applying it practically by using local and readymade teaching materials.

\section{Skill and proficiency on multiliteracies pedagogy : Deficiency for application}

To put multiliteracies pedagogy into practice the teachers should have knowledge, skill and proficiency on it. As multiliteracies pedagogy is based on variety of modes of communication such as mass media, multimedia, and electronic hypermedia, and the cultural and linguistic diversity of the society, the teachers of early grade in Nepal also need to be skilled and have proficiency to apply such emerging and developed features of pedagogy practically in the classroom. In this scenario, the participant Devraj said that while teaching students in the early grade, it is difficult for him to apply multiliteracies pedagogy. So, he dominantly uses traditional literary practice to make the students understand the teaching contents. Oneafternoon, one of us (Principal Investigator, PI) talked to him about the skills and proficiency that he bears for multiliteracies paedagogy. The following is an excerpt of that interaction:

Researcher : What early grade do you teach in?

Devraj : Two and three

Researcher : Why do you feel difficult to apply multiliteracies pedagogy in early grades?

Devraj : I see some teachers are using multimedia projector and audiovisual devices to teach in upper classes. We do not have much more such devices in our school and also we do not have skill to use modern ICT equipments as well.

Researcher : What is the main reason, lack of devices/materials or skill?

Devraj : Lack of skill is main problem in comparison to availability of devices/ materials. Our headteacher provides us devices/ materials when we demand but obtaining skill on it is difficult for us.

Researcher : Have you got any training/workshop on the skill development for multiliteracies pedagogy? 
Devraj : No. Neither local government nor other agencies have provided such training to us.

Researcher : Why?

Devraj : They provide training on other issues but they need to update us on recently developed modern technology and they should orient us to deal with culturally and linguistically diverse classroom.

Researcher : If you get training on skill development for multiliteracies pedagogy, can you apply it in early grade class?

Devraj : Of course. Now-a-days we are using pictures, drawings, songs while we are teaching. If we get training on it, we can teach using modern technology and internet in early grade. (Interview, 22 January, 2020)

The account made by Devraj signifies that the teachers are not skillful and updated regarding skills and proficiency on multiliteracies pedagogy. It is found that new and innovative technologies in today's digital era have created changes in education and these innovations now suggest the possibilities of using new ways of teaching and learning. To address such new innovations and digital technology, at first, the teachers need to be prepared to use it successfully in the classroom. In this aspect, Navehebrahim, (2011, p. 865) mentioned that, "teachers have to concern the values, possibilities, pedagogies and constraints of multimodal literacy and multimedia technologies that result in the emergence of new modes and texts". Devraj asserted that he is interested in teaching through multiliteracies pedagogy if he becomes well trained on it as Tan and Guo (2010) concluded in a study that the teacher was interested to use a multiliteracies approach in her classroom and she also acknowledged the importance of learning 21 st century skills, but she faced a dilemma because teaching learning activity was still concentrating on print literacies. In the same concern, Harikala expressed her ideas as:

I can make flash cards, pictures, and know to play cassette. I show the pictures and flash cards in the classroom. I teach the students through games and puzzles as well. Likewise, I play cassette and teach the students chant, listening and speaking activities, but I do not know to handle modern ICT devices such as video recording, audio recording, internet, you tube, Google etc. No any agencies have trained me in these aspects. I can apply Multiliteracies pedagogy if I am trained. (Interview, 10 March 2020) 
The remarks uttered by Harikala assert that she is curious to use multimodal learning through the Internet being equipped with ICT devices as said by Kulju et al. (2018), multiliteracies pedagogy is a continuum and new technologies has become a part of everyday schooling; but she cannot create a lot of activities based on modern technology because she is not well known and trained on this aspect. The skill and proficiency in teacher on multiliteracies pedagogy is seen as observed in the following vignette:

\section{Vignette 2: Use of materials/ devices}

I sat behind the students' row in round table of Grade 1. The wall was painted with pictures of children, alphabet, numbers, names of vegetables and fruits. A cartoon picture ('Do not make noise' is written under the picture) for making student silence, was hanged on the wall of the classroom. A television was suspended on the wall in front of the class. The teacher was teaching English. She wrote seven questions on the white board and asked the students to write the answer of them. The medium of instruction was Nepali but the students were writing answer in English. There were a lot of visual pictures and television on the wall, but she was not using them for teaching learning purpose. I asked her why she did not use pictures and television for teaching learning activities. She replied that she had not a lot of digital sources (songs, child movies, rhymes, games in pendrive and CD) to play in television. She also did not know operate television efficiently. She told me that she had sometimes used wall pictures to teach according to the context of the lesson. (Field note, 22 January 2020)

The vignette illustrates that the teacher is applying reading and writing modes of literacy much more in the class instead of multiliteracies pedagogy because they do not encompass skill of using modern technological based different modes of learning. HSS has tried to collect the resources for multiliteracy pedagogy. The classroom is decorated with some multimodal-based visual teaching learning materials. The team of school is curious and dedicated for the use of technologybased teaching. The teachers are also desired to teach by following multiliteracy pedagogy but they have lack of skills and proficiency on it. As they are old and experienced but are not updated on modern ICT equipments, Makarlal noted:

I am old and habituated on traditional literacy. I feel easy to teach following reading and writing literacy, but I feel much more difficult to apply multilingual and multimodal approach since I do not know English language and I am also not skilled in the use of modern technology such as recording students' voice in recorder, making film by capturing the role play of students, 
exploring different learning strategis through internet. Even I am old, I can teach following multiliteracy pedagogy but I need skill development training on it. (Interview, 10 March 2020)

The ideas expressed by Makarlal emphasized the use of reading and writing literacy but Mills (2007) made counter argument on it and said that understandings of literacy that are associated exclusively with print are inadequate. According to New London Group (1996), multiliteracies concerns rapidly changing forms of communication and meaning-making tied to mass media, multimedia, and the Internet.

\section{Conclusion}

Regarding understanding and awareness on multiliteracies pedagogy, the teachers do not have very much clear theoretical concept of it. In other words, they cannot define the term multiliteracies pedagogy exactly from linguistic point of view. They know literacy as being able in 'reading' letters and 'writing' them on paper with a pen; and multiliteracies as being literate not only through reading and writing but also using pictures, signs and symbols. They cannot tell the literal meaning of multiliteracies pedagogy but partially they have applied it practically in the classroom as one of them taught a chant by clapping hands, and making gesture which is a form of multiliteracies pedagogy. They are also conscious that there should be the use of multimodal technology in multiliteracies pedagogy to make teaching learning effective.

The teachers are deficient in skill and proficiency in the application of multiliteracies pedagogy efficiently. They do not have proficient skill to use different multimodal channel of communication successfully in the classroom. They usually teach using flashcards, pictures, games and puzzles and by playing cassette for listening and speaking activities. The school lacks the modern ICT based tools and equipments and the teachers who are teaching at early grade do not have skill to use them. They cannot operate television with pendrive and handle modern ICT devices such as audio recording, video recording, making film by capturing the role-play of students, using the Internet, YouTube, google. Lack of skill is the main problem in comparison to availability of modern devices/materials because the headteacher can provide them such devices/ materials when they demand but obtaining skill on it is difficult for them. Neither local government nor other agencies have provided such training to them. They can apply multiliteracies pedagogy if they develop their capacity through training based on the use of modern ICT. Regarding this aspect, 
Kist (2005) suggested that multiliteracies pedagogy will be facilitated if teachers weave new literacies (knowledge associated with the massive growth of electronic information and communications technologies) into the fabric of their classrooms.

In the context of Nepal, multiliteracies pedagogy is not implemented highly in school education. The school administration (SA) needs to be much more conscious and well-equipped to apply it in the classroom. At first, SA tends to provide training to the teachers about multiliteracies pedagogy concerning the classroom diversity from the point of view of multilingualism and multiculturalism; and rapid development of ICT and its connection to the classroom teaching. The SA needs to develop the capacity and abilities of the teachers on these aspects and only then multiliteracies pedagogy can be easily applied in the early grade classroom. At last, it is important that the current pedagogical repertoires of teachers which encompass an approach that is 'teacher-centred', 'chalk and talk' and 'textbookoriented' have to be transformed for successful teaching and learning. For it, the SA needs to launch teacher motivation activities by encouraging them to implement multiliteracies pedagogy effectively and thus the students learn to compete in this complex world.

\section{Acknowledgement}

This study was completed with the support of the Research Division of University Grants Commission, Bhaktapur, Nepal. We would like to acknowledge the financial assistance of UGC, Nepal for encouraging us in research activity, which is an important aspect for our career development in the field of research.

\section{References}

Benjamin, B. (2014). Multiliteracies in the classroom: Emerging conceptions of firstyear teachers. Journal of Language and Literary Education, 10 (1), 114-135. Retrieved from https://files.eric.ed.gov/fulltext/EJ1030724.pdf Blakeslee, A. \& Fleischer C. (2007). Becoming a writing researcher. Mahwah, NJ: Lawrence Erlbaum Associates.

Boche, B. (2014). Multiliteracies in the classroom: Emerging conceptions of first year teachers. Journal of Language and Literacy Education, 10 (1), 114-135. Retrieved from https://eric.ed.gov/?id=EJ1030724

Cope, B., \& Kalantzis, M. (2000). Multiliteracies: Literacy learning and the design of social futures. Psychology Press. 
Cope, B., \& Kalantzis, M. (2015). The things you do to know: An introduction to the pedagogy of multiliteracies. In A pedagogy of multiliteracies (pp. 1-36). Palgrave Macmillan, London. Retrieved from https://pdfs.semanticscholar.org /8f46/75080f8f2037ed6b94d1006c74aaa6c3d98a.pdf

Creswell, J. W. (2012). Educational research: planning, conducting, and evaluating quantitative and qualitative research (4th ed.). Thousand Oaks, CA: Sage.

Elsner, D. (2011). Developing multiliteracies, plurilingual awareness and critical thinking in the primary language classroom with multilingual virtual talking books. Encuentro, 20, 27-38. Retrieved from https:/ebuah.uah.es/dspace/ bitstream/handle/10017/10103/developing_elsner ENCUENTRO_2011. pdf? sequence $=1 \&$ isAllowed $=\mathrm{y}$

Flick. U. (2002). An introduction to qualitative research. London: Sage Publications. Ganapathy, M. (2014).Using multiliteracies to engage learners to produce learning. International Journal of e-Education, e-Business, e-Management and e-Learning, 4(6), 410-422. Retrieved from https://www.researchgate.net/ profile/Malini_Ganapathy/publication/301294955_Using_Multiliteracies_to Engage_Learners_to_Produce_Learning/links/571591ef08ae8ab56695b0ea/ Using-Multiliteracies-to-Engage-Learners-to-Produce-Learning.pdf

Giampapa, F. (2010). Multiliteracies, pedagogy and identities: Teacher and student voices from a Toronto Elementary School. Canadian Journal of Education, 33(2), 407-431. Retrieved from https://files.eric.ed.gov/fulltext/EJ895577.pdf

Hughes, J. M., \& Morrison, L. (2014). The impact of social networking and a multiliteracies pedagogy on English language learners' writer identities. Writing \& Pedagogy, 6(3), 607-631. Retrieved from https://doi.org/10.1558/wap.v6i3.607

Jarho, E. (2017). The knowledge processes framework and multiliteracies in upper secondary school English textbooks ENA 3 Cultural phenomena (LOPS2016), Insights course 3 and On track 3 (Master's thesis). Retrieved from https://repo.tuni.fi/bitstream/handle/10024/101991/GRADU1505301822. pdf ? sequence $=1 \&$ isAllowed $=y$

Kalantzis, M., \& Cope, B. (2012). Literacies. Cambridge: Cambridge University Press. Khadka, S. (2014). New media, multiliteracies, and the globalized classroom (Doctoral thesis). Retrieved from https://surface.syr.edu/cgi/viewcontent. cgi ? article $=1055 \&$ context $=$ etd

Kist, W. (2005). New literacies in action: Teaching and learning in multiple media. New York: Teachers College Press. 
Kothari, C.R. (2004). Research methodology: methods and techniques. Jaipur: New Age International Publishers.

Kulju, P., Kupiainen, R., Wiseman, A. M., Jyrkiainen, A., Koskinen-Sinisalo, K. L., \& Makinen, M. (2018). A review of multiliteracies pedagogy in primary classrooms. Language and Literacy, 20 (2), 80-101. Retrieved from https:// journals.library.ualberta.ca/langandlit/index.php/langandlit/article/view/29333

May, S. (1997). Critical ethnography. In N. Hornberger (Eds.), Research methods and education. The encyclopedia of language and education (pp. 197206). Dordrecht: Kluwer.

Mills, K. A. (2006). Critical framing in a pedagogy of multiliteracies. Voices, Vibes, Visions: Hearing the Voices, Feeling the Vibes, Capturing the Visions. Retrieved from https://eprints.qut.edu.au/4844/1/4844_1.pdf

Mills, K. A. (2007). “Have you seen Lord of the Rings?” Power, pedagogy, and discourses in a multiliteracies classroom. Journal of Language, Identity, and Education, 6(3), 221-241. Retrieved from https://eprints.qut.edu.au/6742/1 JLIE_Mills_Author_Version_2006.pdf

Mills, K. A. (2009). Multiliteracies: Interrogating competing discourses. Language and Education, 23(2), 103-116. doi: 10.1080/09500780802152762

Navehebrahim, M. (2011). Multiliteracies approach to empower learning and teaching engagement. Procedia-Social and Behavioral Sciences, 29, 863-868. Retrieved from https://pdf.sciencedirectassets.com/277811/1s2.0 S1877042811X00228/1s2.0-S1877042811027765/main.pdf

Neville, M. (2015).“Improving multimodal literacy through learning by design.” In Cope, Bill and Kalantzis, Mary (Eds.), A pedagogy of multiliteracies (pp. 210-230). Houndmills, Basingstoke, Hampshire: Palgrave Macmillan. New London Group. (1996). A pedagogy of multiliteracies: Designing social futures. Harvard Education Review, 66 (1), 60-92.

Simon, R. (2011). On the human challenges of multiliteracies pedagogy. Contemporary Issues in Early Childhood, 12(4), 362-366. Retrieved from: https://journals.sagepub.com/doi/pdf/10.2304/ciec.2011.12.4.362

Souzandehfar, M., Saadat, M., \& Sahragard, R. (2014). The significance of multimodality/multiliteracies in Iranian EFL learners' meaning-making process. Iranian Journal of Applied Linguistics, 17(2), 115-143. Retrieved 
from: https://ijal.khu.ac.ir/files/site1/user_files_795657/archive-A-10-3-7275bfa0e.pdf

Tan, L., \& Guo, L. (2010). From print to critical multimedia literacy: One teacher's foray into new literacies practices. Journal of Adolescent \& Adult Literacy, 53(4), 315324. doi: 10.1598/JAAL.53.4.5

\section{Appendix I}

\section{Guideline Questions}

1. Please tell me your name and experience of involving in teaching profession.

2. Tell me linguistic and cultural diversity of the children of this school.

3. Have you studied about multiliteracies pedagogy? Do you have more ideas about it?

4. How do you perceive the use of multiliteracies pedagogy in early grades?

5. How do you regard the use of print literacy (reading and writing) or multimodes during teaching in the classroom?

6. Do you use oral, visual, audio, gestural, tactile, and spatial modes in teaching?

7. Do you have skills and proficiency in the use of multiliteracies pedagogy in classroom teaching?

8. What skills and knowledge do you need to apply multiliteracies pedagogy in early grades?

9. What are essentials thing you need to be awared to use multiliteracies pedagogy in early grades?

10. Do you belief on multiliteracies pedagogy? Why? Is there appropriate infrastructure in your school for it? 